\title{
Floral biology of Tropaeolum majus L. (Tropaeolaceae) and its relation with Astylus variegatus activity (Germar 1824) (Coleoptera: Melyridae)
}

\author{
MARIA EMÍlIA P.F. SILVA ${ }^{1}$, ROSILDA M. MUSSURY ${ }^{1,3}$, MARIA DO CARMO VIEIRA ${ }^{2}$, \\ VALTER V. ALVES JÚNIOR ${ }^{1}$, ZEFA V. PEREIRA ${ }^{3}$ and SILVANA P.Q. SCALON ${ }^{2}$ \\ ${ }^{1}$ Programa de Pós-Graduação em Entomologia e Conservação da Biodiversidade, Universidade Federal da Grande Dourados/UFGD, \\ Faculdade de Ciências Biológicas e Ambientais, Rodovia Dourados-Itahum, Km 12, 79804-970 Dourados, MS, Brasil \\ ${ }^{2}$ Programa de Pós-Graduação em Agronomia/Produção Vegetal, Universidade Federal da Grande Dourados/UFGD, \\ Faculdade de Ciências Agrárias, Rodovia Dourados-Itahum, Km 12, 79804-970 Dourados, MS, Brasil \\ ${ }^{3}$ Programa de Pós Graduação em Biologia Geral/Bioprospecção, Universidade Federal da Grande Dourados/UFGD, \\ Faculdade de Ciências Biológicas e Ambientais, Rodovia Dourados-Itahum, Km 12, 79804-970 Dourados, MS, Brasil \\ Manuscript received on December 15, 2009; accepted for publication on July 6, 2010
}

\begin{abstract}
Tropaeolum majus L. (nasturtium) is a culture popularly known by its medicinal, ornamental and culinary utility. This work aimed to evaluate the interaction between Astylus variegatus (Germar 1824) (Coleoptera: Melyridae) and the nasturtium flowers associated to the weeks of flourishing, in order to conceive the floral mechanisms used by the species to attract $A$. variegatus. The insects collection was achieved with an entomologic net by the sweeping method, during the weekly flowering, at two hours, from $7 \mathrm{am}$ to $5 \mathrm{pm}$. The studies of floral biology were carried out in twenty flowers by the analysis of measures and the arrangement of the floral parts. The nasturtium flower offers pollen and nectar to the insect as a compensation. However, it was observed that $A$. variegatus only collects pollen as a nutritious resource. Tropaeolum majus presents several flowers for each individual and, during the visits, A. variegatus walked throughout the interior of the flower, among the stamens and contacting the ventral region of its body, and while passing through the stigma it lodged the pollen. Sometimes, it uses the internal cavity for sheltering and mating. The visits occurred preferably on the second and fifth weeks of flourishing, with a populational fluctuation between $9 \mathrm{am}$ and $11 \mathrm{am}$.
\end{abstract}

Key words: nasturtium, coleoptera, pollinization.

\section{INTRODUCTION}

Tropaeolum majus L. (Tropaeolaceae) is known as nasturtium, indian cress, caper, wormseed, garden balsam, bloody-flower, mexican water cress and big-nasturtium (Corrêa 1926, Font Quer 1993, Dematti and Coan 1999). This species is widely used as a medicinal and ornamental plant; it is a durable, melliferous, natural dyeing and non-conventional potherb, and it has an enormous importance for the commercial apiculture (Ortiz de Boada and Cogua 1989). Due to the beauty of its flowers and leaves, it is used in landscaping projects (Bremness 1993)

Correspondence to: Rosilda Mara Mussury

E-mail: maramussury@ufgd.edu.br and for nutritious use, with its leaves and flowers being used in salads and sandwiches (Sangalli et al. 2004).

Astylus variegatus (Germar 1824) (Coleoptera: Melyridae) are coleopters that are found on the flowers of native and exotic plants in South America (Matioli et al. 1990). The adults are found from January to June at high environmental temperatures (Rossetto and Rossetto 1976). They feed on the sweating of the plants, nectar and pollen, and are not considered as main pests in cultivations (Willemstein 1987, Embrapa 2000). In sunflower, Camargo and Amabile (2001) observed that adults of $A$. variegatus attack the stem, and their larvae attack the roots of the plants. According to Cruz et 
al. (2008), the adult is a pest in corn plantations due to the mechanical damages to the floral organs. It was also observed in literature that $A$. variegatus may compete with bees for floral resources, contributing for the reduction of nectar disposal to other pollinators. The floral morphology and the insect behavior are closely related to the pollinated efficiency from any floral visitor. The flowers developed mechanisms like colored petals, scent, nectar compensation, pollen, essences and oils to attract the interested floral visitor and to obtain the pollination. Yet, not all floral visitors are efficient pollinators since there is an adaptation among the characteristics of the flower and its effective pollinator (Couto and Couto 2006). The pollinators have time synchronisms with their main nourishment sources, which allow them to be present in a higher number when the plant offers more flowers (Freitas 1998). As the role of $A$. variegatus on T. majus flowers is not established, the current work aimed to: 1 . study its interaction with the nasturtium flowers during the weeks of flourishing; 2 . figure out the floral mechanisms used by the species to attract $A$. variegatus.

\section{MATERIALS AND METHODS}

This study was carried out at the Experimental Area of Medicinal Plants at Universidade Federal da Grande Dourados (UFGD), in Dourados-MS, from April to July, 2008. The size of the area used for the study was $300 \mathrm{~m}^{2}$, which was divided into six quadrants. The insects collection was weekly achieved with an entomologic net by the sweeping method, during the flowering, at $7 \mathrm{am}, 9 \mathrm{am}, 11 \mathrm{am}, 1 \mathrm{pm}, 3 \mathrm{pm}$ and $5 \mathrm{pm}$, for seven weeks, at 7 days, no matter the climatic conditions. For each schedule, five sweeping nets were achieved at random points, and the chosen ones were excluded from the next samplings. Later, the collected individuals were wrapped into plastic bags with cotton soaked in ethyl acetate and taken to the laboratory to be selected and counted. The mean number of insects caught on the flowers was calculated during the weeks of flowering.

The studies of floral morphology were carried out in twenty flowers that were collected and observed in a stereoscope microscope, which allowed the identification and the characterization of the floral structures, as well as the definition of the flowering phases. For describing these phases, the buds were measured and analyzed as for the arrangement of the floral parts. For verifying the scent emission, the floral parts separated from three individuals were put into a glass recipient with a lid and, then, uncovered and smelled after thirty minutes (Dafni 1992).

\section{RESULTS AND DISCUSSION}

The study on flower morphology leads to the comprehension of a plant-pollinator interaction and, so, in this current work, T. majus morphology was determinant for A. variegatus attraction. T. majus L. is a herbal and low plant, with irregular, campanulated, axillary, flashy, solitary, hermaphordite, asymmetrical and zigomorphic flowers. The corolla is pentamerous, varying from yellow to red. The calyx appears as a single part, but it is divided into five sepals on the apex, and one of them is elongated, forming the calcar where the nectary is placed. There are eight stamens (Fig. 1) with different sizes (Fig. 2), being four bigger, three medium and one smaller, but occasionally the flower may have nine stamens, free and with anthers (Fig. 3) turned outside and rimous, which are yellow and with a fixed basis and diteca insertion.

The gynoecium (Fig. 4), which ranges from greenwish to yellowish, presents a stigma divided into three parts, an elongated style and a superior ovary, with three carpels joined on the basis, containing one egg on each loculus and with an apical placentation.

It was noted that the anthesis is diurnal and the flower duration is six days, on average. The scent of the flower was strongly smelled on the petals and stamens, defining an aroma of a rotten material or in decomposition.

Five phases of development were determined for the nasturtium flowers according to the differences on the buds size and on the position of floral verticils (Figs. 5 and 6). On the first and second phases (bud), the calyx completely covered the bud. The bud presented a $4 \mathrm{~mm}$ length with eight green stamens, three of them were slightly bigger than the others. The anthers were closed and the styles were not apparent. When the petals reached $1.5 \mathrm{~cm}$ length, they stood out the calyx and four bigger stamens were observed. In the beginning of the pre-anthesis, it was noted that the 


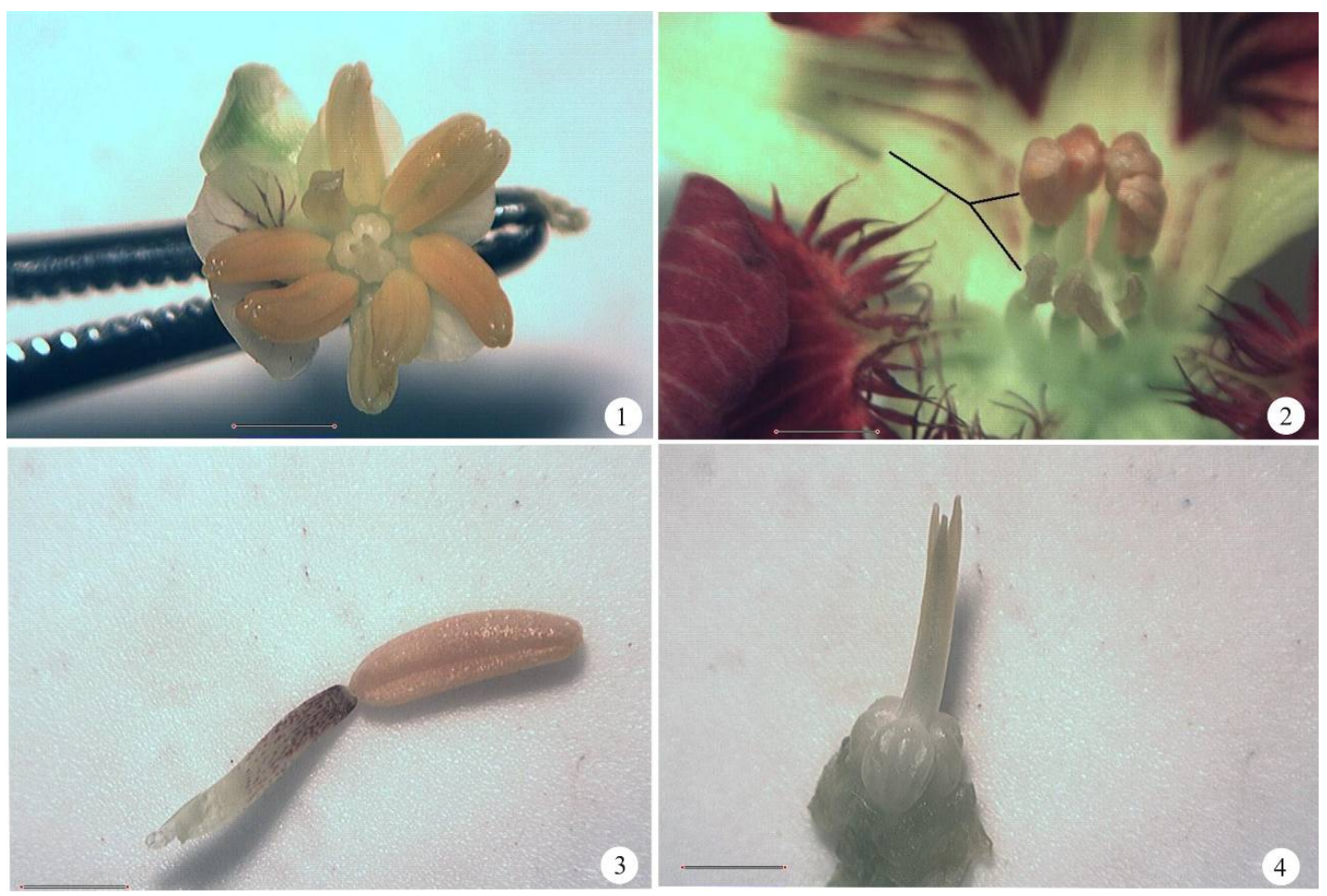

Figs. 1-4 - Tropaeolum majus L. flowers. 1. Group of stamens; 2. Detail of the stamens with different sizes; 3. Stamen; 4. Gynoecium. Bars $=2 \mathrm{~cm}$.

petals were unrolling and the bud was $2 \mathrm{~cm}$ length. As the pre-anthesis evolved (3), the petals were kept away and a non-synchronized increase of the stamens was observed. The anthers presented a slight curvature to the outside, the petals were alternately arranged with the sepals and the anthers curvature was bigger, concluding their opening. On the anthesis (4), the petals were totally separated and arranged among the sepals, and with the flower presenting a diameter of $4.5 \mathrm{~cm}$ to $4.8 \mathrm{~cm}$. The nectar guide is well visible. The androecium presented four bigger stamens, two medium and two smaller ones. The anther dehiscence was longitudinal with a totally twist to the outside (an extrorse dehiscence). On the post-anthesis or senescence (5), the petals presented purplish.

In relation to $A$. variegatus presence, it was observed that the $4^{\text {th }}$ phase (anthesis) was preferred (Fig. 5), with only one or several visitants (Fig. 7) formed by three to six on each flower (Figs. 8 and $8 \mathrm{a}$ ). The period of the visit on a flower varied from 2 to 10 minutes and, later, the insects could also visit other opened flowers nearby or abandoned the place.
On this phase, T. majus flowers remained opened for six days, with the petals well kept away exposing the stigmas and the stamens. This easily allowed the insect to contact both the receptive stigmas and the stamens at the moment they were releasing pollen.

The fact that T. majus presents stamens with different sizes may favor the pollination and the nutrition by A. variegatus. The difference on the size of the stamens helps to attract and dispose the pollen as an easy-access resource. Lopes and Machado (1996) observed a difference on the size of the stamens of Swartzia pickelii flowers (leguminosae-Faboidae) and gave them the role of attracting the foragers.

During its visits to the flowers, A. variegatus searched for a shelter and a place for copulation and nutrition, collecting only pollen. During its visits, $A$. variegatus walked through all the interior of the flower and among the stamens, contacting the ventral region of its body and, while passing through the stigma, it deposited the pollen. Sometimes, they arrived inside the flower and stayed there piled up and motionless, indicating that this was a shelter place. Occasionaly the 


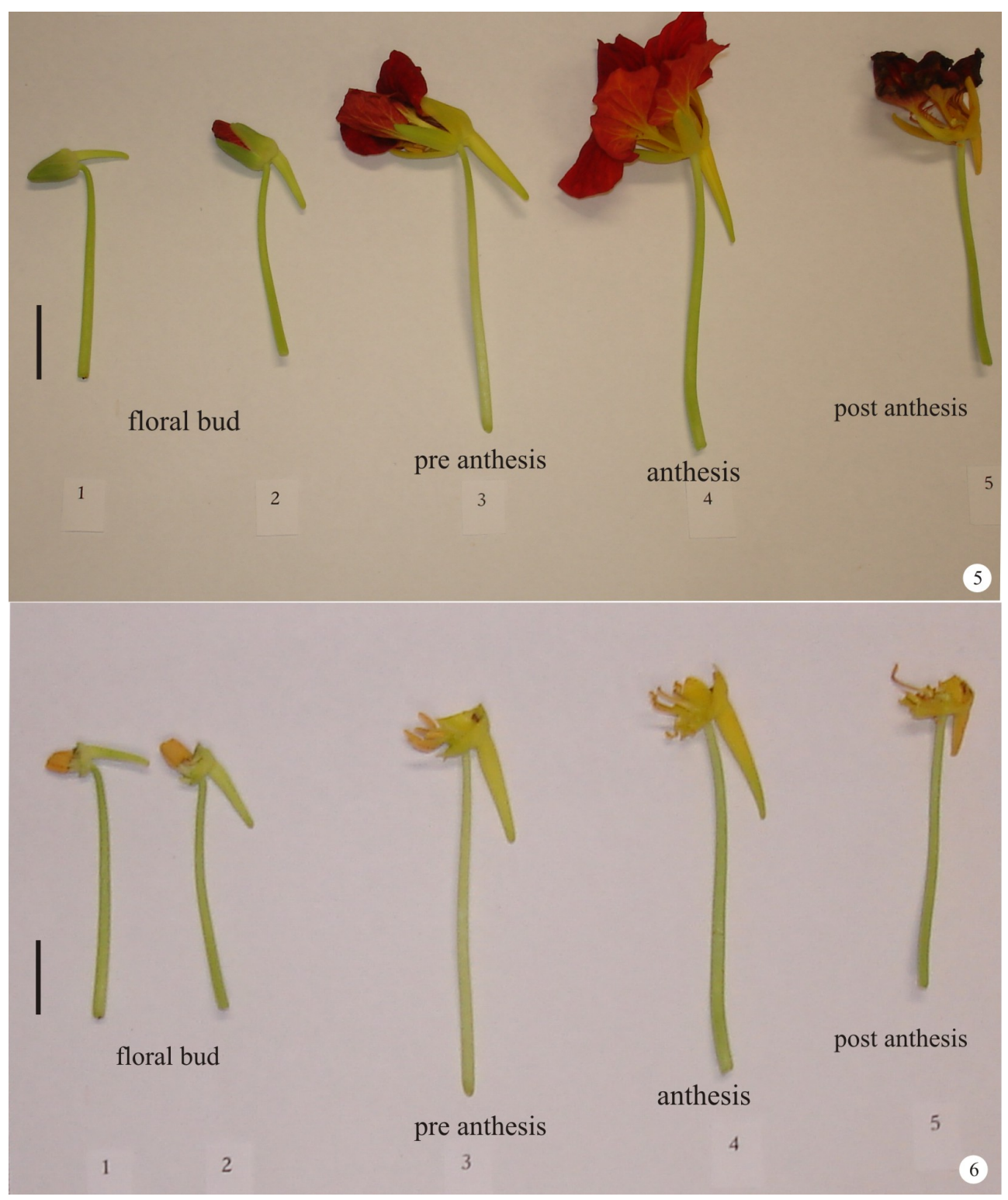

Figs. 5-6 - Tropaeolum majus L. flower, development of the floral bud, flower in anthesis and postanthesis (from left to right); 5. Phases of flower development with protective verticils; 6 . Phases of flower development with protective verticils removed. Bars $=1 \mathrm{~cm}$.

copulation occurred. At other times, they were observed near the calcar, but they did not reach the nectar deposited inside it. On corn flowers, A. varigatus was observed collecting nectar (Embrapa 2000), but on this work this activity was not confirmed probably because the nectary was placed in the calcar and was difficult to access.

Studies on insect-plant interaction for the Tropaeolum genus are scarce. However, in T. pentaphyllum
Lam., Fabbri and Valla (1998) observed that the flower presents typical characteristics of the ornitophilous syndrome. Two species of Trochilidae, Vespidae, Halictidae and Apidae were observed, as well as one species of Syrphidae and Aphida as floral visitors, but no coleopteran visits were mentioned.

In general, A. variegatus may be considered as a possible pollinator due to its behavior during the visits. It presents grains of pollen held on the abdomen 


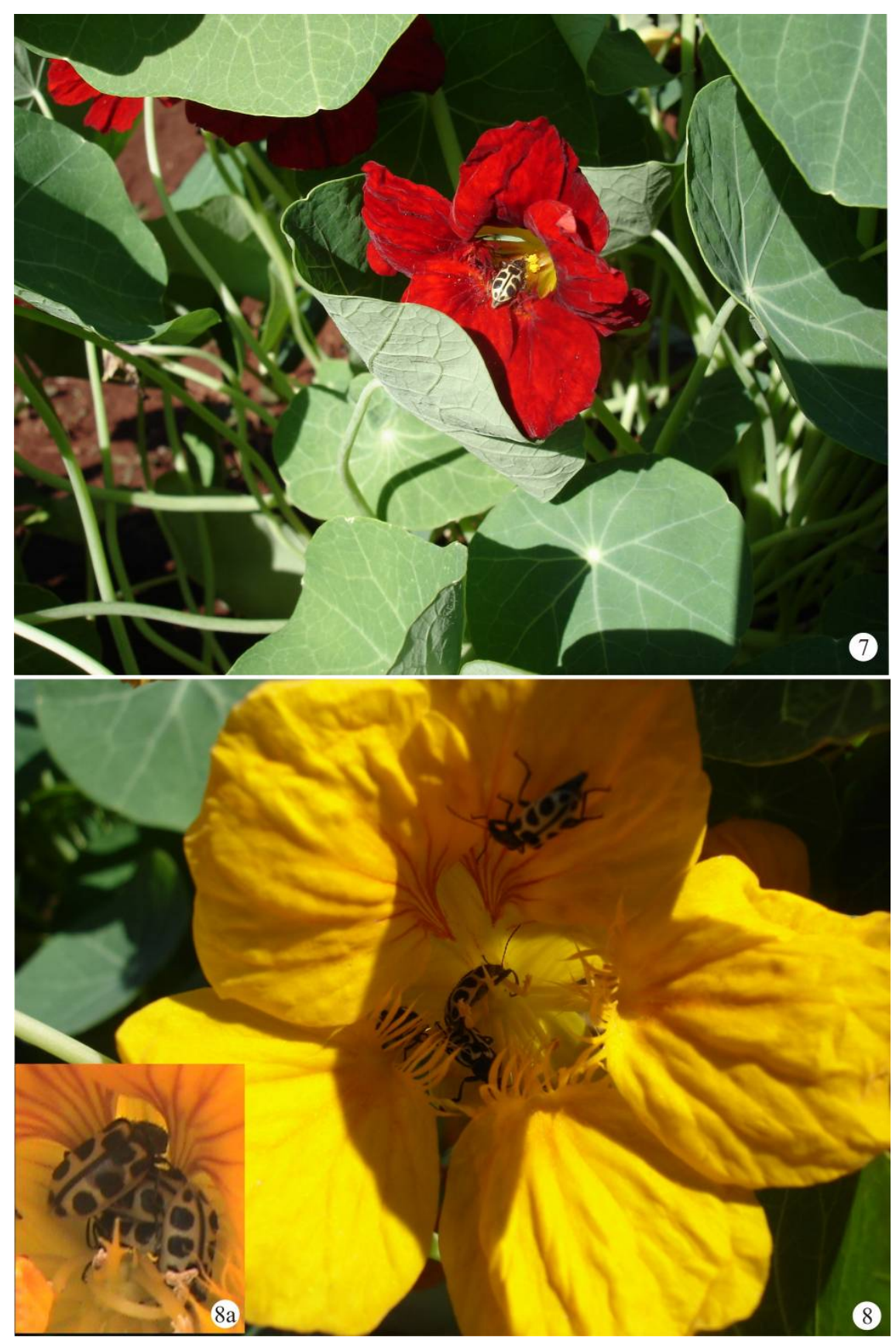

Figs. 7-8 - Astylus variegatus on a Tropaeolum majus L. flowers (7. individual; 8. attached; 8a. detail).

since it walks through all the reproductive system of the flower. Moreover, the compatibility of size between $A$. varigatus and the flowers offers an efficient contact with their reproductive organs. Based on considerations by Couto and Couto (2006), the adaptation between the floral characteristics of T. majus and A. variegatus behavior is confirmed and, therefore, this species is pres- ented as a possible pollinator. According to Gullan and Cranston (2007), the coleoptera visit the flowers mainly due to its pollen attraction (Faegri and Van Der Pilj 1979). The flower may use its nectar as a way to easy the access of the coleopera, which does not happen to T. majus. Similarly to the interaction described above, in Grobya amherstiae Lindl. (Orchidaceae: Cyrtopodi- 


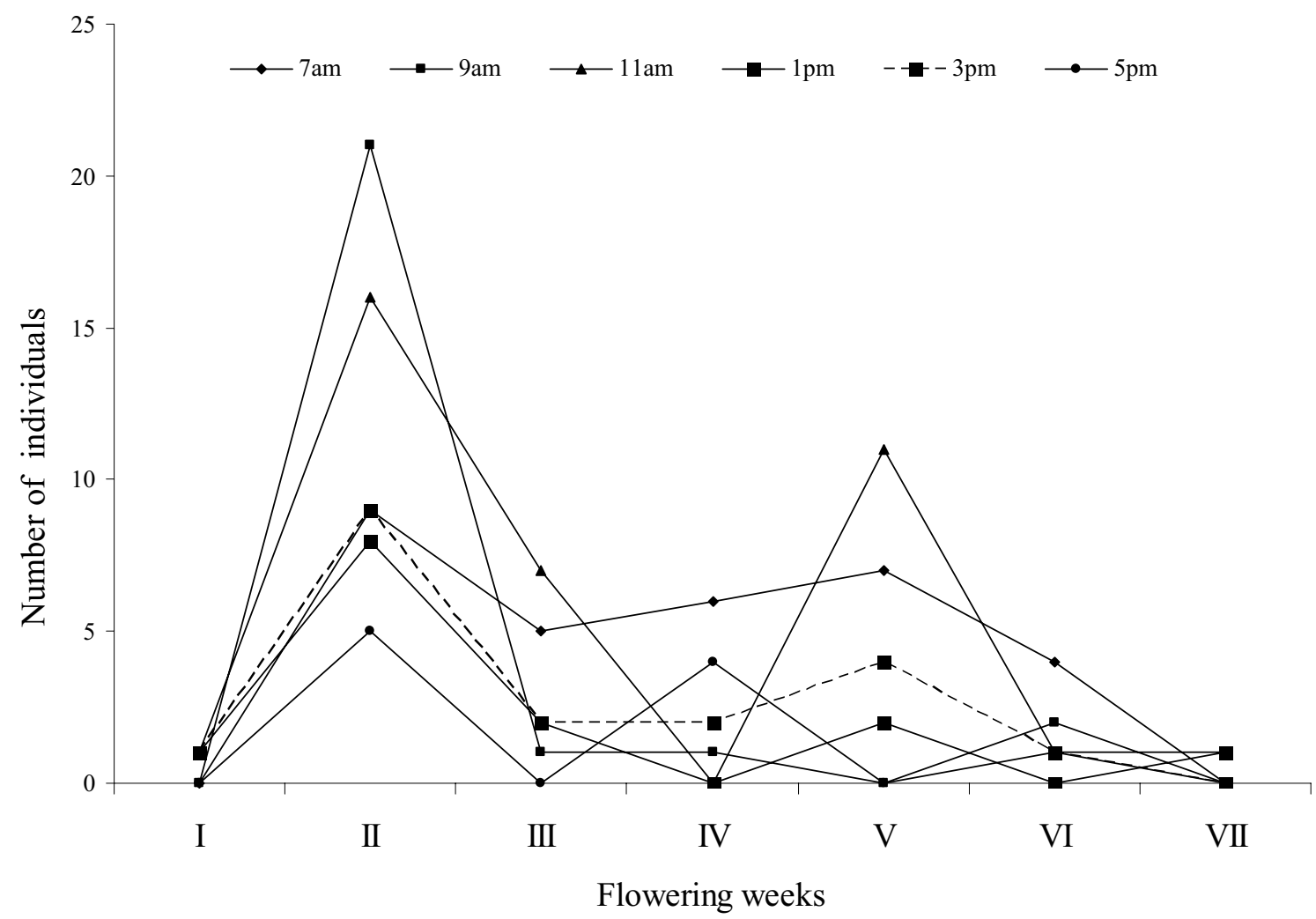

Fig. 9 - Temporary populational fluctuation of Astylus variegatus on a Tropaeolum majus flowers (nasturtium) during the flowering weeks of the culture, from $7 \mathrm{am}$ to $5 \mathrm{pm}$.

inae), Mickeliunas et al. (2006) observed the beetle of the Montella genus (Curculionidae: Centrinini) during all the flowering. They observed an agglomeration and, during the visits, the beetle displaced the anther of $G$. amherstiae, consumed the walls that share the pollinia and handled the pollinarium up to the stigma.

Other reports about beetles as possible pollinators are known by Silva and Domingues Neta (2010). While studying Duguetia marcgraviana Mart. (Anonaceae), they found Lobiopa sp., Colopterus sp. (Nitidulideae) and Epitragus sp. (Tenebrionidae) into its floral chamber, with a high frequency of visits on the flowers and the presence of pollen in their bodies.

It was verified that, on the first week of flowering, the number of $A$. variegatus was low probably due to few flowers for each individual (around 5). On the second week of flowering, the number of flowers on anthesis was higher, with sixteen flowers for each individual and, therefore, A. variegatus frequency increased significantly. It visited the flowers from $7 \mathrm{am}$ to $5 \mathrm{pm}$, with a populational peak between 9am and 11am
(Fig. 9). On the third and fourth weeks, it was noticed a reduction on the number of insects. The standard of T. majus synchronized flowering had probably favored the reduction on the insects frequency as the flowers from the previous week (second one) on anthesis had already been senescent. The low number of insects observed from $7 \mathrm{am}$ to $11 \mathrm{am}$ on the third week and at $7 \mathrm{am}$ on the fourth week probably occurred because few flowers had available pollen.

On the fifth week, it was observed an increase in the number of flowers on anthesis probably due to the factor that increased the number of insects on the nasturtium flowers.

On the sixth and seventh weeks, it was observed a lower frequency of the insects on the flowers, since some of them were on senescence or producing fruit. So, the insect did not have access to the sought resource.

In the presence of this explanation, it is observed that the frequency of these insects is related to the number of flowers for each individual, with the flowers offer a reasonable amount of pollen as a nutritious resource 
and a wide internal cavity, favoring the shelter. Confirming the presented data, Barroso et al. (2002) observed that, in most Anonaceae genera, the floral chamber is used by the beetles as a place for sheltering against natural enemies and environmental adversities, working as a place for mating.

\section{ACKNOWLEDGMENTS}

The authors thank to Conselho Nacional de Desenvolvimento Científico e Tecnológico (CNPq) for supporting the first author with a Master scholarship, and to Professor Dc. Sergio Ide (Insituto Biológico São Paulo-SP) by the insect identification.

\section{RESUMO}

Tropaeolum majus L. (capuchinha) é uma cultura muito conhecida pelo seu valor medicinal, ornamental e culinário. O objetivo do trabalho foi avaliar a interação entre Astylus variegatus (Germar 1824) (Melyridae) com as flores de capuchinha, associado às semanas de florescimento, visando entender os mecanismos florais utilizados pela espécie na atração de A. variegatus. A coleta dos insetos foi realizada com rede entomológica pelo método varredura durante a floração, semanalmente, a cada duas horas, no período de 7 às 17 horas. Os estudos da biologia floral foram realizados em vinte flores, analisando as medidas e disposição das peças florais. A flor de capuchinha oferece ao inseto pólen e néctar como recompensa, contudo, foi observado que $A$. variegatus coleta apenas pólen como recurso alimentar. Tropaeolum majus apresenta várias flores por indivíduo sendo que durante as visitas A. variegatus caminhava por todo o interior da flor, entre os estames contatando a região ventral de seu corpo e, ao passarem pelo estigma, depositava o pólen. Em alguns momentos, utiliza a cavidade interna para abrigo e acasalamento. As visitas ocorreram preferencialmente na segunda e quinta semanas de florescimento com pico populacional entre as 9 e 11:00h.

Palavras-chave: capuchinha, coleóptera, pólen.

\section{REFERENCES}

Barroso GM, Peixoto Al, ichaso ClF, Costa CG, Guimarães EF AND Lima HC. 2002. Sistemática de Angiospermas do Brasil. $2^{\text {a }}$ ed., Universidade Federal de Viçosa, Viçosa, Brasil, 309 p.

BREMness L. 1993. Manual del herborista. Madrid: Raízes, $285 \mathrm{p}$.
CAmargo AJP AND Amabile RF. 2001. Identificação das Principais Pragas do Girassol na Região Centro-Oeste. EMBRAPA/CPAC, 4 p. EMBRAPA/CPAC, Comunicado Técnico 50.

CORRÊA MP. 1926. Dicionário das plantas úteis do Brasil e das exóticas cultivadas. Rio de Janeiro: Ministério da Agricultura; Instituto Brasileiro de Desenvolvimento Florestal 1: 674 .

Couto RHN And Couto LA. 2006. Apicultura: Manejo e produtos. $3^{\mathrm{a}}$ ed., Jaboticabal: FUNEP, 193 p.

Cruz I, Valicente FH, Santos JP, Waquil JM AND ViAnA PA. 2008. Manual de identificação de pragas do milho e de seus principais agentes de controle biológico. Editora: EMBRAPA, 192 p.

DAFNi A. 1992. Pollination Ecology; A Practical Approach, Oxford University Press, Oxford, 250 p.

DEMATTI MESP AND COAN RM. 1999. Jardins com plantas medicinais. Jaboticabal: FUNEP, 65 p.

EMBRAPA. 2000. Pragas iniciais em milho, $\mathrm{n}^{\circ}$ 49, fev.

FABBRI LT AND VAlla JJ. 1998. Aspectos de la biología reproductiva de Tropaeolum pentaphyum (Tropaeolaceae). Darwiniana 3(1-4): 51-58.

FAegri K AND VAN Der PIJL L. 1979. The principles of pollination ecology. $3^{\text {rd }}$ ed., Pergamon Press, Oxford, United Kingdom, 244 p.

FONT QUER P. 1993. Plantas medicinales: el dioscórides renovado. Barcelona: Labor, 1033 p.

FREITAS BM. 1998. Uso de programas racionais de polinização em áreas agrícolas. Mensagem Doce, São Paulo 46: $16-20$.

Gullan PJ AND CRAnston PS. 2007. Os Insetos: Um resumo de Entomologia. In: BIOLOGIA REPRODUTIVA DE Insetos E Plantas. São Paulo: Roca, p. 246-262.

LOPES AVF AND MACHADO ICS. 1996. Biologia floral de Swartzia pickelii (Leguminosae-Papilionoideae) e sua polinização por Eulaema spp. (Apidae-Euglossini). Rev Bras Bot 19: 17-24.

Matioli JC, Rossi MM And CARvalho CF. 1990. Ocorrência e distribuição mensal de Astylus variegatus (Germar, 1824) e A. sexmaculatus (Perty, 1830) (Coleoptera: Dasytidae) em alguns municípios do Estado de Minas Gerais. An Soc Entom Brasil 19: 373-382.

Mickeliunas L, Pansarin ER And Sazima M. 2006. Biologia floral, melitofilia e influência de besouros Curculionidae no sucesso reprodutivo de Grobya amherstiae Lindl. (Orchidaceae: Cyrtopodiinae). Revista Brasil Bot 29(2): 251-258. 
ORTIZ DE BOADA D AND COGUA J. 1989. Reconocimiento de granos de polen de algunas plantas melíferas en la sabana de Bogotá. Agronomia Colombiana 6: 52-63.

Rossetto CJ AND Rossetto D. 1976. Astylus variegatus (Germar,1824) (Coleóptera: Dasytidae) danificando sorgo. Bragantia 35: 131-132.

SAngalli A, Vieira MC And Zarate NAH. 2004. Resíduos Orgânicos e Nitrogênio na Produção de Biomassa da Capuchinha (Tropaeolum majus L.) 'JEWEL'. Cien Agrot 28(4): 831-839.
Silva CA And Domingues Neta AM. 2010. Aspectos reprodutivos e visitantes forais de Duguetia marcgraviana Mart. (Annonaceae) na região sudoeste de Mato Grosso. Revista Biotemas 23(1): 69-76.

Willemstein SC. 1987. An evolutionary basis for pollination ecology. Leiden: Leiden University Press, 425 p. (Botanical Series, 10). 